\title{
The relationship of sex and ectoparasite infestation in the water rat Scapteromys aquaticus (Rodentia: Cricetidae) in La Plata, Argentina
}

\author{
Marcela Lareschi \\ CONICET. Centro de Estudios Parasitológico y de Vectores. Calle $2 \mathrm{~N}^{\circ}$ 584, 1900 La Plata, Argentina; \\ mlareschi@cepave.com.ar
}

Received 10-VI-2003. Corrected 20-II-2004. Accepted 31-V-2004.

\begin{abstract}
I studied the relationship between sex and infestation with ectoparasites in the water rat Scapteromys aquaticus from La Plata river marshland, Argentina. The Relative Density's Index (RDI) for males was 3.90\% (females 3.60\%). A total of 2653 ectoparasites were collected on 33 male hosts, and 1945 on 31 females. Ectoparasite specific richness $(\mathrm{S})$ and diversity $(\mathrm{H})$ were $\mathrm{S}=14, \mathrm{H}=1.17$ on males, and $\mathrm{S}=10, \mathrm{H}=1.52$ on females. The similarity between male and female rodents according to their ectoparasites was $75.00 \%$. Although no ectoparasite species showed significant mean abundance (MA) differences between host sexes ( $<<0.05)$, and only Laelaps manguinhosi prevalence was significantly higher on male hosts $(\mathrm{N}=2.01, \mathrm{p}<0.05)$ in this study, there are reasons to think that the sex of the water rat affects ectoparasite burden and specific richness. This information has epidemiological potential because the closely relatedScapteromys tumidus is involved in the transmission of Rickettsia coronii, which causes Marsella fever in humans. Rev. Biol. Trop. 54(2): 673-679. Epub 2006 Jun 01.
\end{abstract}

Key words: ectoparasites, host sex, Scapteromys aquaticus, water rat, La Plata river marshland, Argentina.

The Genus Scapteromys Waterhouse, 1837 (Rodentia: Cricetidae: Sigmodontinae) is known from southern Paraguay, extreme southern Brazil, Uruguay, and northeastern Argentina (Redford and Eisenberg 1992), and Scapteromys aquaticus Thomas, 1920 (the water rat) is the only species reported from Argentina (Galliari et al. 1996, D'Elía and Pardiñas 2004), which has previously been treated as a subspecies of Scapteromys tumidus (Waterhouse, 1837) (Galliari et al. 1996). The water rat inhabits Chaco, Entre Ríos and Buenos Aires provinces and it is very abundant in marshy places and flooded areas along La Plata and Paraná rivers (Massoia 1961, Massoia and Fornes 1964, Kravetz 1972, Lareschi 1996, Liljeström and Lareschi 2002). It is semiaquatic, excellent swimmer and its ability and agility in climbing tall plants contribute to its success in such areas (Massoia and Fornes 1964). Like most wild rodent species, the water rat is associated with arthropod ectoparasites, which are important vectors of pathogens that cause diseases in human beings and domestic and wild animals, and whose reservoirs are wild rodent hosts. Besides, these arthropods may play an important role in epizootics and in the perpetuation of diseases among those wild rodents (Strandtmann and Wharton 1958, Linardi and Guimarães 2000). However, since ectoparasite-host association is the result of evolutionary and ecological processes, intraspecific variations of host population related to sex may affect infestation parameters and indexes of its ectoparasites. The most important variations related to host sex are factors such as relative size and differences in the skin and its covering, difference in blood hormonal levels due to stress or reproductive condition, and behavioral factors 
such as differences in grooming, nesting and mobility (Marshall 1981).

Ectoparasites of $S$. aquaticus have been the subject of some studies in Argentina, most of them conducted on their taxonomy and morphology, as well as lists of species and localities of collection (Ronderos 1965, Castro et al. 1987, 1991, Castro and Cicchino 1987, Mauri 1965, Mauri and Mosquera 1987, Lareschi 1996, Lareschi and Sánchez López 2000). Infestation parameters and indexes of some ectoparasite species have been examined by Lareschi (1996), Lareschi and Iori (1998), Liljeström and Lareschi (2001, 2002), Nava et al. (2003), and Lareschi et al. (2003). Few investigations have been conducted on the relationship between arthropods and wild rodents of different sexes, (Lareschi and Cicchino 2002, Liljeström and Lareschi 1998, 2001, Lareschi and Liljesthröm 2000), and only one (Lareschi 2004) have considered acarine and flea species simultaneously.

Populations of $S$. aquaticus from Buenos Aires province localities have been previously studied, and intraspecific behavioral, physiological and morphological differences between males and females have been noticed (Massoia 1961, Cueto et al. 1995, Sánchez López 1998). The subject of the present study is to analyze the interrelationship between host sex and the infestation with ectoparasites in La Plata river marshland.

\section{MATERIALS AND METHODS}

The marginal forest at Punta Lara, situated in an ecotonal area between the GuayanoBrasileña and Patagonian zoogeographic Neotropical Subregions (Ringuelet 1962), was the selected study area. It is located $50 \mathrm{~km}$ from Buenos Aires city, on the costal fringe of La Plata river (34⒋ $7^{\prime} \mathrm{S}$; 58 ${ }^{\circ} 1^{\prime} \mathrm{W}$ ) (Buenos Aires Province), where the South American subtropical humid forest reaches its southern limit as a riverine forest. However, human interventions have greatly modified the original vegetation and the resulting landscape is a mixture of native and exotic forest species (Dascanio et al. 1994).

Samples of rodents were obtained in accordance with regulations and policies from Dirección de Administración y Difusión Conservacionista del Ministerio de Asuntos Agrarios de la Provincia de Buenos Aires. Rodents were captured from March 1990 to December 1991 in 22 trapping sessions. Captures were realized with a $7.5 \mathrm{~cm}$ x $15 \mathrm{~cm}$ x $8 \mathrm{~cm}$ live-trap cages using a rectangular grid with 30 trap stations (3X10), 3 m apart. Traps were baited with oiled bread and activated for one night at each trapping session. The rodents were killed with sulfuric ether and frozen in individual plastic bags. The furs of the hosts were examined with magnifying lens in order to obtain ectoparasites. Specialists in endoparasites (CEPAVE) have collected filarioids and helminthes from the host's cavities. Ectoparasites were preserved in $70 \%$ ethanol and mounted on permanent slides following conventional techniques for each group and identified. Representative individuals of rodents and ectoparasites were housed at the Collections of the Departments of Vertebrate Zoology and Entomology respectively, La Plata Museum, Argentina.

The following indexes and parameters were calculated for each host sex: Relative Density's Index: RDI = [number of captured rodents / number of traps] X 100; Species Richness: $\mathrm{S}=$ number of species; Shannon Diversity's Index: $\mathrm{H}=-\sum$ [p $\left.i \ln \mathrm{p} i\right]$, where $\mathrm{p} i=$ proportion of each species in the sample (Begon et al. 1988); Css Sorensen index (Css= $2 \mathrm{C} / \mathrm{Sm}+\mathrm{Sf}$; were $\mathrm{C}=$ number of ectoparasite species in both host sexes; Sm and Sf: ectoparasite specific richness in male and female hosts respectively) (Morales and Pino 1987): Specificity index SI (SI= number of ectoparasites of a particular species in only one host sex X 100 / sum of number of ectoparasites of a particular species in total number of hosts) (Marshall 1981); Mean Abundance: MA = total number of individuals of a particular parasite species in a particular host sex / total number of hosts of that sex; Prevalence: $\mathrm{P}=$ (number 
of hosts parasited with a particular parasite species / total number of hosts examined for that parasite species) x 100 (Bush et al. 1997). The significance of MA and P differences between host sexes were analyzed using Student's $t$-test $(\mathrm{p}<0.05)$ (Morales and Pino 1987), and Normal Deviation $(\mathrm{N})(\mathrm{p}<0.05)$ (Snedecor and Cochran 1979) respectively.

\section{RESULTS}

Sixty-four individuals of $S$. aquaticus were captured. The relative density was RDI $=3.90 \%$ for males and RDI $=3.60 \%$ for females. A total of 4,598 ectoparasites were collected. The species of arthropods were the following: Acari, Laelapidae: Androlaelaps fahrenholzi (Berlese, 1911), Androlaelaps rotundus (Fonseca, 1935), Gigantolaelaps wolffshoni (Oudemans, 1910), Laelaps echidninus Berlese, 1887, Laelaps manguinhosi Fonseca, 1935, Laelaps paulistanensis Fonseca, 1935; Macronyssidae: Ornithonyssus bacoti (Hirst, 1913); Ixodidae: Ixodes loricatus Neumann,1899; Trombiculidae: Eutrombicula alfreddugesi (Oudemans, 1910). Insecta, Phthiraptera, Hoplopleuridae: Hoplopleura scapteromydis Ronderos, 1965; Siphonaptera, Rhopalopsyllidae: Polygenis (Neopolygenis) atopus (Jordan \& Rothschild, 1922), Polygenis (Neopolygenis) massoiai Del Ponte, Polygenis (Polygenis) axius axius (Jordan \& Rothschild), Polygenis (Polygenis) bohlsi bohlsi (Wagner, 1937), Polygenis (Polygenis) platensis platensis (Jordan \& Rothschild, 1908).

Values of ectoparasite specific richness and diversity were $\mathrm{S}=14, \mathrm{H}=1.17$ on male hosts, and $\mathrm{S}=10, \mathrm{H}=1.52$ on females. The similarity between male and female rodents according to their ectoparasites was Css $=75.00 \%$. The number of ectoparasites, MA, P and SI from every ectoparasite species are detailed on Table 1 for each host sex. No ectoparasite species showed significant MA differences between host sexes, and only L. manguinhosi prevalence was significantly higher on male hosts.

TABLE 1

Number of ectoparasites, Mean Abundance (burden range), Student's t-test values, Prevalence, Normal Deviation values and Specific Index of ectoparasites collected on Scapteromys aquaticus males and females from

La Plata river marshland, Argentina (March 1990-December 1991)

\begin{tabular}{|c|c|c|c|c|c|c|c|c|c|c|}
\hline \multirow[b]{3}{*}{ Ectoparasites } & \multicolumn{7}{|c|}{ Hosts } & & \multirow[b]{3}{*}{$N$} & \multirow[b]{3}{*}{ SI } \\
\hline & \multicolumn{3}{|c|}{ Males $(\mathrm{N}=33)$} & \multirow[b]{2}{*}{ SI } & \multicolumn{4}{|c|}{ Females $(\mathrm{N}=31)$} & & \\
\hline & $\mathrm{N}^{\circ}$ & MA & $\mathrm{P}(\%)$ & & $\mathrm{N}^{\circ}$ & MA & $t$ & $\mathrm{P}(\%)$ & & \\
\hline Androlaelaps fahrenholzi & 115 & $3.48(0-35)$ & 72.72 & 110.13 & 87 & $2.80(0-17)$ & 1.3 & 70.96 & 0.16 & 88.61 \\
\hline Androlaelaps rotundus & 1 & $0.03(1)$ & 3.23 & 192.31 & 0 & 0.00 & 0.00 & 0.00 & 1.46 & - \\
\hline Gigantolaelaps wolffsohni & 1 & $0.03(1)$ & 3.03 & 60.00 & 2 & $0.06(0-1)$ & 0.05 & 6.45 & 0.64 & 120.00 \\
\hline Laelaps echidninus & 1 & $0.03(0-1)$ & 3.03 & 192.31 & 0 & 0.00 & 0.00 & 0.00 & 1.46 & - \\
\hline Laelaps manguinhosi & 1413 & $42.82(0-427)$ & 90.90 & 134.61 & 623 & $20.09(0-91)$ & 1.49 & 67.74 & $2.37^{*}$ & 63.15 \\
\hline Laelaps paulistanensis & 5 & $0.15(0-2)$ & 12.12 & 136.36 & 2 & $0.06(0-1)$ & 0.09 & 6.45 & 0.32 & 54.55 \\
\hline Ornithonyssus bacoti & 51 & $1.64(0-11)$ & 45.45 & 31.78 & 279 & $9.00(0-175)$ & 1.35 & 51.61 & 0.49 & 174.42 \\
\hline Lxodes loricatus & 19 & $0.67(0-4)$ & 42.42 & 115.52 & 18 & $0.68(0-10)$ & 0.35 & 25.80 & 1.43 & 117.24 \\
\hline Eutrombicula alfreddugesi & 125 & $3.78(0-26)$ & 39.39 & 68.72 & 227 & $7.32(0-90)$ & 1.05 & 58.06 & 1.52 & 133.09 \\
\hline Hoplopleura scapteromydis & 888 & $26.91(0-366)$ & 48.48 & 109.84 & 680 & $21.93(0-147)$ & 0.33 & 45.16 & 0.26 & 89.51 \\
\hline Polygenis (Neopolygenis) atopus & 31 & $0.94(0-6)$ & 39.39 & 105.62 & 26 & $0.84(0-17)$ & 0.54 & 22.58 & 1.07 & 94.38 \\
\hline Polygenis (Neopolygenis) massoiai & 1 & $0.03(1)$ & 3.03 & 192.31 & 0 & 0.00 & 0,00 & 0.00 & 0.00 & - \\
\hline Polygenis (Polygenis) axius axius & 0 & 0.00 & 0.00 & - & 1 & $0.03(0-1)$ & 0.00 & 3.23 & 0.00 & 192.31 \\
\hline Polygenis (Polygenis) bohlsi bohlsi & 1 & $0.03(0-1)$ & 3.03 & 192.31 & 0 & 0.00 & 0.00 & 0.00 & 0.00 & - \\
\hline Polygenis (Polygenis) platensis platensis & 1 & $0.03(0-1)$ & 3.03 & 192.31 & 0 & 0.00 & 0.00 & 0.00 & 0.00 & - \\
\hline \begin{tabular}{|c|} 
TOTAL \\
\end{tabular} & 2653 & $80.39(1-443)$ & 100 & & 1945 & $62.74(1-323)$ & 0.73 & 100 & 0.00 & \\
\hline
\end{tabular}

$\mathrm{N}^{\circ}=$ Number of ectoparasites, MA $=$ Mean Abundance (burden range), $t=$ Student's $t$-test, $\mathrm{P}=$ prevalence, $\mathrm{N}=\mathrm{Normal}$ Deviation and $\mathrm{SI}=$ Specific Index. ${ }^{*} \mathrm{p}<0.05$. 


\section{DISCUSSION}

The results obtained showed higher ectoparasite burden on male rodents in agreement with previous studies from Tiradentes and Belo Horizonte (Botelho 1990), Minas Gerais State, Brazil. Besides, male hosts showed higher ectoparasite specific richness. Larger size of males (Massoia 1961) might benefit them with higher burden and specific richness of ectoparasites. However, males showed lower ectoparasite diversity than females. Out of the 15 ectoparasite species collected, two mite and four flea species infested only one host sex; however, all of them showed low values of $\mathrm{P}$ and MA that suggest secondary ectoparasitehost associations. In comparison with other wild rodent species which inhabit in Punta Lara marshland, the highest MA, P, diversity and specific richness of ectoparasites showed by $S$. aquaticus suggest that it is usually an alternative host for those ectoparasites generally associated with other host species in the same locality (Lareschi 1996, 2000). A. rotun$d u s$, mostly associated with Akodon azarae in Punta Lara (Lareschi 1996), and L. echidninus, usually associated with Rattus species (Strandtmann and Wharton 1958), infested exclusively male individuals of the water rat. P. (N.) massoiai, P.(P.) b. bohlsi and P. (P.) $p$. platensis, also infested only male hosts. Studies from Buenos Aires province localities, show that male individuals of $S$. aquaticus have larger average movements, and home range size, with a greater chance of contact with individuals of the same and other species, than females do (Cueto et al. 1995, Sánchez López 1998). Hence, these behavioral characteristics of males may give them better possibilities of being colonized by ectoparasites.

Although differences between prevalence and mean abundance from every ectoparasite species for each host sex, as well as the total of these parameters (except L. manguinhosi, whose $\mathrm{P}$ was significantly higher on males) were not significant, a tendency towards host sex effect is observed. Few specimens of fleas of every species collected, do not permit to make further analysis of the data, but they were mostly collected on males. Some previous studies support that male hosts are more heavily infested by fleas (Marshall 1981), while others indicate that females are (Soliman et al. 2001, Botelho 1990). Concerning acarines, not only A. rotundus and L. echidninus were collected exclusively on male hosts, but L. manguinhosi, A. fahrenholzi and L. paulistanensis also show higher values of their infestation parameters on that host sex. These results are in agreement with studies on lelapid mites from other host species and localities (Botelho 1990, Soliman et al. 2001). In contrast with the above mentioned species, the values of MA, P and SI of $G$. wolffsohni, O. bacoti, and E. alfreddugesi were higher on female hosts. Both G. wolffsohni, and $O$. bacoti are mostly recovered from the nests of their hosts (Strandtmann and Wharton 1958), and E. alfreddugesi spends its non-parasitic biological stages on the soil. In Buenos Aires localities, females of $S$. aquaticus show shorter dispersal movements than males, as well as longer stay in the nests taking care of the offsprings (Cueto et al. 1995, Sánchez López 1998). Then, these characteristics may allow them to encounter the above mentioned ectoparasites. Only I. loricatus $\mathrm{P}$ was higher on male hosts, while the values of MA and SI were similar between both host sexes. In the present study, H. scapteromydis infestation parameters were not significantly different between both host sexes. Some reports on Hoplopleura species show similarities on female and male hosts, while others support that males have greater populations in relation to larger body size of individuals of this sex of certain species (Marshall 1981). Studies on population dynamics of $H$. scapteromydis show that it is not significantly different between both host sexes, and the spatial distribution of its eggs on the host body is also similar. However, the proportion of eggs layed on every site is significantly different between male and female rodents (Liljeström and Lareschi 1998, Lareschi and Liljeström 2000). In addition to the above mentioned ecological and behavioral characteristics related to each host sex, morphological features 
such as relative size and differences in the skin and its covering, as well as physiological factors such as difference in blood hormonal levels due to stress or reproductive condition, also cause variation in ectoparasite infestation parameters and indexes (Marshall 1981). Although they are not analyzed in the present study, they should not be discarded.

The results obtained in the present research support that the sex of the water rat affect principally its ectoparasite burden and specific richness. Besides, a tendency towards host sex effect on the prevalence and abundance of some species is also observed. This information, which contributes to a better knowledge of the interrelationship between ectoparasites and S. aquaticus from La Plata river marshland, is important to understand the role of ectoparasite vectors and mammalian reservoirs in the maintenance of diseases in the study area, and the possibilities of dissemination of pathogens. In Uruguay, the closely related species $S$. tumi$d u s$ is involved in the transmission of Rickettsia coronii, which cause Marsella fever in humans, and whose vector is the tick Amblyoma triste (Conti Diaz 2001). Although at the moment the above mentioned rickettsiae has not been reported from Argentina, the results obtained in the present study are important from an epidemiological point of view, and will contribute to further studies.

\section{ACKNOWLEDGMENTS}

This study is part of my Doctoral Thesis at La Plata National University, Argentina. I express my gratitude to the dissertation committee: G. Liljesthröm (CEPAVE, Argentina), D.C. Castro (MLP, Argentina), R. Ojeda (CRICYT, Argentina) and C. de Villalobos (MLP, Argentina). I am also gratitude to U. Pardiñas (CENPAT, Argentina) and C. Galliari (Zoológico de La Plata, Argentina) for the identification of the rodents, and to A. Iori (Universitá La Sapienza, Italy) for her help in the identification of most of the fleas.

\section{RESUMEN}

Se estudió la interrelación entre el sexo de la rata de agua Scapteromys aquaticus y su infestación por ectoparásitos en la ribera del Río de la Plata, Argentina. El índice de densidad relativa de los machos fue $3.90 \%$ y el de las hembras $3.60 \%$. Se recolectó 2653 ectoparásitos de 33 machos y 1945 de 31 hembras. La riqueza (S) y diversidad específicas $(\mathrm{H})$ de los ectoparásitos fueron $\mathrm{S}=14, \mathrm{H}=$ 1.17 en los machos y $\mathrm{S}=10, \mathrm{H}=1.52$ en las hembras. La similitud entre sexos fue del $75.00 \%$. Si bien ningún ectoparásito en este estudio mostró diferencias significativas en su abundancia media entre los hospedadores de diferente sexo $(\mathrm{p}<0.05)$ y sólo la prevalencia de Laelaps manguinhosi fue significativamente mayor en los machos $(\mathrm{N}=2.01, \mathrm{p}<0.05)$, otros datos sugieren que sí existe un patrón de diferencias sexuales.

Key words: ectoparasitos, hospedero, Scapteromys aquaticus, rata de agua, río La Plata, humedal, Argentina.

\section{REFERENCES}

Begon, M., J.L. Harper \& C.R. Towsend. 1987. Ecología, individuos, poblaciones y comunidades. Omega, Barcelona, $886 \mathrm{p}$.

Botelho, J.R. 1990. Ectoparasitos de alguns roedores de Belo Horizonte, MG.: Estudos fenéticos, cladísticos e de interacao ectoparsito/hospedeiro. Doctoral Thesis. Universidad Federal de Minas Gerais. Belo Horizonte, Brasil.

Bush, A.O., K.D. Laffert, J.M. Lotz \& A.W. Shostak. 1997. Parasitology meets ecology on its own terms: Margolis et al. Revisited. J. Parasitol. 83(4): 575-583.

Castro, D.C. \& A. Cicchino. 1987. Lista referencial de los Anoplura y Mallophaga (Insecta) conocidos como parásitos de mamíferos en la Argentina. Rev. Soc. Entomol. Argent. 44(3-4): 357-369.

Castro, D.C, A. Cicchino \& C. De Villalobos. 1991. A comparative study of the external chorionic architecture of the eggs of some Neotropical species of the Genus Hoplopleura Enderlein, 1904 (Phthiraptera, Anoplura). Revta. bras. Ent. 35(4): 663-669.

Castro, D.C., R. Mauri, A. Cicchino \& S. Mosquera. 1987. Ectoparásitos de roedores de la Provincia de Buenos Aires, Argentina (Acarina, Anoplura, Mallophaga y Suctoria). Rev. Soc. Entomol. Argent. 44(34): 317-327.

Conti Diaz, I.A. 2001. Rickettssiosis por Rickettsia coronii (fiebre botonosa del Mediterráneo o fiebre de 
Marsella). Estado actual en Uruguay. Rev. Med. Uruguay. 17: 119-124.

Cueto, V.R., M. Cagnoni \& M.J. Piantanida. 1995. Habitat use of Scapteromys tumidus (Rodentia: Cricetidae) in the delta of the Paraná River, Argentina. Mammalia 59: 25-34.

Dascanio, L.M., M. Barrera \& J. Frangi. 1994. Biomass structure and dry matter dynamics of subtropical alluvial and exotic Ligustrum forest at the Río de la Plata, Argentina. Vegetatio 115: 61-76.

D’Elía, G. \& U.F.J. Pardiñas. 2004. Systematics of Argentinean, Paraguayan, and Uruguayan swamp rats of the Genus Scapteromys (Rodentia, Cricetidae, Sigmodontinae). J. Mammal. 85: 897-910.

Galliari, C.A., U.F.J. Pardiñas \& F. Goin. 1996. Lista comentada de los mamíferos argentinos. Mastozoología Neotropical 3: 39-61.

Kravetz, F.O. 1972. Estudio del régimen alimentario, períodos de actividad y otros rasgos ecológicos en una población de "ratón hocicudo" (Oxymycterus rufus platensis Thomas) de Punta Lara. Acta Zool. Lill. 29: 201-212.

Lareschi, M. 1996. Nuevas citas de ácaros parásitos de roedores para la provincia de Buenos Aires. Rev. Soc. Entomol. Argent. 55(1-4): 66.

Lareschi, M. 2000. Estudio de la Fauna Ectoparásita (Acari, Phthiraptera y Siphonaptera) de Roedores Sigmodontinos (Rodentia: Muridae) de Punta Lara, Provincia de Buenos Aires, Tesis Doctoral, Universidad Nacional de La Plata, La Plata, Argentina.

Lareschi, M. 2004. Ectoparásitos Asociados a los Machos y a las Hembras de Oxymycterus rufus (Rodentia: Muridae). Estudio Comparativo en la Selva Marginal del Río de La Plata, Argentina. Rev. Soc. Entomol. Argent. 63(3-4): 39-44

Lareschi, M. \& A. Cicchino A 2002. Abundancia, prevalencia y preferencia de Amblyopinodes gahani gahani (Fauvel, 1901) (Coleoptera: Staphylinidae) en roedores sigmodontinos de la Reserva Selva Marginal de Punta Lara, Provincia de Buenos Aires, Argentina. Acta Zool. Mex. (Nueva Serie) 85: 1-9.

Lareschi, M. \& A. Iori. 1998. Nuevas citas de Siphonaptera (Rhopalopsyllidae; Hystrichopsyllidae) parásitos de roedores de la provincia de Buenos Aires, Argentina. Revta. bras. Ent. 41(2-4): 165-167.

Lareschi, M. \& G. Liljesthröm . 2000. Distribución espacial de los huevos de tres especies del género Hoplopleura
Enderlein(Phthiraptera:Hoplopleuridae)ectoparásitas de roedores (Rodentia: Muridae: Sigmodontinae). Rev. Soc. Entomol. Argent. 59(1-4): 1-6.

Lareschi M., J. Notarnicola, G. Navone \& P.M. Linardi. 2003. Arthropod and Filarioid Parasites Associated with Wild Rodents from the Northeast Marshes of Buenos Aires, Argentina. Mem. Inst. Oswaldo Cruz. 98: 673-677.

Lareschi, M. \& M.I. Sánchez López. 2000. Ectoparásitos (Phthiraptera y Acari) de roedores (Rodentia: Muridae: Sigmodontinae) en el delta bonaerense del Río Paraná, Argentina. Rev. Soc. Entomol. Argent. 59(1-4): 17-19.

Liljesthröm, G. \& M. Lareschi. 1998. Aspectos de la ecología de Hoplopleura scapteromydis (Phthiraptera: Hoplopleuridae) ectoparásito de Scapteromys tumidus en Punta Lara. Rev. Soc. Entomol. Argent. 57(14): $115-120$.

Liljeström, G. \& M. Lareschi. 2001. Fecundity of Hoplopleura scapteromydis (Phthiraptera, Hoplopleuridae) ectoparasite of Scapteromys aquaticus (Rodentia: Muridae) in Rio de la Plata marshland, Argentina. J. Parasitol. 87(5): 951-956.

Liljeström, G. \& M. Lareschi. 2002. Estudio preliminar de la comunidad ectoparasitaria de roedores sigmodontinos en el partido de Berisso, provincia de Buenos Aires: 257-260. In D. Salomón (comp.). Actualizaciones en artropodología sanitaria Argentina. Fundación Mundo Sano, Buenos Aires.

Linardi, P.M. \& L.R. Guimarães. 2000. Sifonápteros do Brasil, MZUSP, FAPESP, São Paulo, Brasil. 291 pp.

Marshall, A.G. 1981. The ecology of ectoparasitic insects. New York, USA. 459 p.

Massoia, E. 1961. Nota sobre Cricétidos de la Selva Marginal de Punta Lara. Publ. Mus. Mem.Cs. Nat. Mar del Plata 1: 115-134.

Massoia, E. \& A. Fornes 1964. Notas sobre el gen. Scapteromys (Rodentia: Cricetidae) I. Sistemática, distribución geográfica y rasgos etoecológicos de $S$. tumidus (Waterhouse). Physis 24: 279-297.

Mauri, R. 1965. Acaros Mesostigmata parásitos de vertebrados de la República Argentina. Seg. Jorn. Entomoepidem. Argent. 1: 65-73.

Mauri, R. \& S. Mosquera. 1987. Nómina actualizada de ectoparásitos (Acarina y Suctoria) de roedores de ambientes acuáticos de la provincia de Buenos Aires (Argentina). Neotropica 33(89): 50. 
Morales, G. \& L.A. Pino. 1987. Parasitología cuantitativa. Fundación Fondo Editorial. Acta científica venezolana. Caracas, Venezuela. 132 p.

Nava, S., M. Lareschi \& D. Voglino. 2003. Interrelationship between ectoparasites and wild rodents from Northeastern Buenos Aires Province, Argentina. Mem. Inst. Oswaldo Cruz. 98: 45-49.

Redford, K.H. \& F. Eisenberg. 1992. Mammals of the Neotropics The Southern Cone, Vol. 2. Univ. of Chicago. 430 p.

Ringuelet, R.A. 1962. Rasgos faunísticos de las Reservas Naturales de la Provincia de Buenos Aires. Physis 23(64): 8392.

Ronderos, R. 1965. Notas sobre Anoplura Argentinos (Insecta). Neotrópica 11(35): 46-49.
Sánchez López, M.I. 1998. Factores que limitan la abundancia de los roedores muridos en el Delta del Paraná. Doctoral Thesis, Universidad Nacional de Buenos Aires, Buenos Aires, Argentina.

Snedecor, G.W. \& W.G. Cochran. 1979. Métodos estadísticos. Continental, México. 703 p.

Soliman, S., A.S. Marzouk, A.J. Main \& A.A. Montasser. 2001. Effect of sex, size, and age of commensal rat hosts on the infestation parameters of their ectoparasites in a rural area of Egypt. J. Parasitol. 87: 1308-1316.

Strandtmann, R.W. \& G.W. Wharton. 1958. Manual of Mesostigmatid Mites. In C.E. Yunker (ed.). University of Maryland, USA. 330 p. 
